\title{
Literasi bagi Anggota PKK sebagai Upaya Meningkatkan Ketaatan terhadap Kebijakan Pemerintah di Tengah Pandemi COVID-19
}

\author{
${ }^{1}$ Setyasih Harini*, ${ }^{2}$ Andri Astuti Itasari \\ ${ }^{1}$ Program Studi Hubungan Internasional, Universitas Slamet Riyadi Surakarta, Indonesia \\ ${ }^{2}$ Program Studi Ilmu Komunikasi, Universitas Slamet Riyadi Surakarta, Indonesia \\ *Corresponding Author: \\ E-mail: setyasih.rini@gmail.com
}

Received:
1 January 2021
Revised:

15 April 2021
Accepted:

15 May 2021
Published:

31 May 2021

\begin{abstract}
Abstrak
Proses pembangunan membutuhkan keterlibatan perempuan. Perempuan sebagai bagian dari masyarakat memiliki peran penting dalam perubahan sosial. Peningkatan peran perempuan salah satunya dipengaruhi oleh kebijakan yang dikeluarkan pemerintah. Ketika kebijakan yang dikeluarkan pemerintah belum dipahami oleh perempuan menjadikannya sebagai kelompok yang terkungkung dalam ketidaknyamanan. Permasalahan tersebut dapat ditanggulangi dengan mengadakan pendekatan dengan perempuan dalam kelompoknya melalui literasi dalam bentuk sosialisasi, diskusi dan pelatihan. Perempuan yang tergabung dalam PKK terutama yang berusia lebih dari 50 tahun dari Desa Wirogunan Kecamatan Kartasura Kabupaten Sukoharjo belum mampu memahami kebijakan pemerintah terkait pencegahan terhadap penularan Virus Corona. Kegiatan pengabdian kepada masyarakat ini bertujuan untuk meningkatkan pemahaman anggota PKK terhadap penyebaran virus yang berskala internasional, kebijakan pemerintah dan melatih menggunakan gawai secara bijak agar bisa memilah informasi secara benar. Metode yang digunakan dalam kegiatan ini berupa sosialisasi dan pelatihan. Kegiatan tersebut berjalan lancar dan sesuai rencana. Anggota PKK mengalami perubahan positif yakni semakin paham sekaligus menaati kebijakan pemerintah yang berwujud peraturan serta lebih bijaksana dalam menggunakan gawai.
\end{abstract}

Kata kunci: Perempuan; kebijakan; pemerintah; literasi.

\begin{abstract}
The development process requires the involvement of women. Women as part of the community have an important role in social change. One of the increasing roles of women is influenced by government's policies. When the government's policies are not yet understood by women, making them a group that is confined in discomfort. These problems can be overcome by approaching women in their groups through literacy in the form of socialization, discussion and training. Women who are members of the PKK especially those aged over 50 years from Wirogunan Village, Kartasura District, Sukoharjo Regency have not been able to understand government policies related to prevention of Corona Virus transmission. This community service activity aims to increase PKK members' understanding of the spread of the virus on an international scale, government policy and train to use smartphone wisely so that they can sort out information correctly. Method that used in this activity are socialization and training. This activity went well and according to the plan. PKK members experienced positive changes, which increasingly understood and obeyed government policies in the form of regulations and wiser in using smartphone.
\end{abstract}

Keywords: Women; policies; government; literacy 


\section{PENDAHULUAN}

Perempuan dan pembangunan bisa diibaratkan seperti dua sisi mata uang. Perempuan dapat menjadi bagian dan sekaligus sebagai obyek atau sasaran dari proses pembangunan. Di sisi lain, perempuan juga menjadi subyek dari pelaksanaan pembangunan itu sendiri. Hal tersebut terlihat melalui program pembangunan berkelanjutan yang salah satu targetnya adalah pemberdayaan perempuan. Dalam tulisannya Claudia Garcia, Moreno dan Avni Amin (2016) menjelaskan bahwa melalui pembangunan berkelanjutan diharapkan dapat mengeliminasi kekerasan terhadap perempuan dengan harapan dapat meningkatkan persamaan gender dan pemberdayaan perempuan. Perempuan seringkali belum berperan banyak dalam proses pembangunan seperti yang dijelaskan oleh Bhalotra (2018) bahwa perempuan hanya sebagai sarana untuk memperluas hasil pembangunan agar lebih berorientasi pada anak dan perempuan, untuk meningkatkan perekonomian masyarakat serta mengurangi korupsi. Dari situ menunjukkan bahwa peran perempuan dalam pembangunan perlu ditingkatkan, bukan lagi sebagai obyek namun subyek.

Terkait dengan keberhasilan pelaksanaan pembangunan, World Bank (2001) menyebutkan bahwa kesetaraan gender sangat diperlukan. Kemampuan negara untuk berkembang dan meningkatkan kesejahteraan masyarakatnya diperlukan pemerintah yang efektif. Pemerintah dikatakan efektif dalam proses pembangunan jika peraturan yang dikeluarkan menjadikan perempuan bukan semata-mata sebagai obyek sasaran namun yang menguntungkan bagi kemajuan dirinya (Probosiwi, 2015). Hal ini dipertegas dengan pernyataan dari Valeria Esquivel (2016) bahwa perempuan hendaknya diberdayakan dalam proses pembangunan bukan sematamata untuk memenuhi hak asasinya namun bisa menjadi tenaga penggerak perubahan sosial agar terjadi relasi "kekuasaan" yang seimbang dengan laki-laki. Kedua penulis tersebut hendak menyampaikan bahwa keberhasilan pembangunan secara langsung maupun tidak dipengaruhi oleh seberapa besar peran perempuan sebagai anggota masyarakat.

Di banyak negara berkembang menunjukkan bahwa budaya tradisional cenderung patriarki (Agarwal, 1994, Sullivan 1994, Jewkes dkk, 2015). Dalam kondisi seperti ini, perempuan kurang mendapat akses terhadap bidang pendidikan, fasilitas kesehatan dan pekerjaan yang membangun kreativitas. Inilah yang dalam konsep Sen (1990) diistilahkan sebagai "missing woman" untuk menggambarkan kurangnya akses perempuan dalam mendapatkan fasilitas penunjang kehidupan layak. Untuk itu perempuan hendaknya memperoleh hak untuk mendapatkan akses pendidikan yang cukup sehingga mampu mengambil keputusan sendiri terhadap dirinya, meningkatkan kemampuannya agar bisa memperoleh pendapatan sendiri atau membangun perekonomian sendiri tanpa mengubah budaya dan pola perilaku yang berlaku dalam masyarakat (Samarakoon dan Rasyad Parinduri, 2015).

Perempuan pada masa sekarang sudah tidak diragukan lagi akan kesempatannya dalam upaya pemberdayaan. Pemberdayaan secara konseptual merupakan proses multidimensi sosial dalam membantu masyarakat memperoleh kontrol terhadap dirinya sendiri. Sebagai suatu proses maka pemberdayaan membutuhkan waktu yang tidak sebentar agar kemampuannya dalam menentukan pilihan-pilihan terhadap hidup untuk memperoleh manfaat dapat terwujud. Dalam hal ini perempuan yang diberdayakan diharapkan dapat mempertahankan proses yang dijalaninya guna mendapat manfaat dari kehidupan rumah tangga, komunitas dan masyarakat luas (Alfarez dan Lopez, 2013). Perempuan yang telah mendapat pemberdayaan menunjukkan peningkatan keadilan gender. Hak dan kewajibannya sebagai individu dan anggota masyarakat dapat dilaksanakan tanpa harus tergantung pada laki-laki.

Perempuan yang mengalami pemberdayaan sekaligus menunjukkan kebebasannya untuk berkembang sesuai kemampuannya dalam membuat pilihan tanpa dibatasi oleh tradisi kuat yang ada dalam lingkungannya. Pemberdayaan perempuan saat ini menjadi hal urgen dalam proses pembangunan berkelanjutan. Pembangunan berkelanjutan menjadi sebuah program baru dari 
PBB dimaksudkan untuk meningkatkan kualitas kehidupan masyarakat. Pembangunan sebelum beberapa dekade lalu sering diidentikkan sebagai pertumbuhan ekonomi dan kapasitas produksi dari suatu negara sehingga menimbulkan ketimpangan yang dalam antara negara kaya dan miskin (Gunduz, 2004; Drexhage dan Murphy, 2010). Melalui pembangunan berkelanjutan diharapkan proses yang dilaksanakan sesuai dengan kebutuhan masyarakat sekarang dan generasi mendatang bukan hanya dari faktor ekonomi.

Pembangunan berkelanjutan dilihat dari tujuannya sangatlah mulia untuk mengurangi gap antara negara maju dengan berkembang. Untuk itulah ada 17 sasaran dari pembangunan berkelanjutan yang salah satunya adalah pemberdayaan perempuan guna mengurangi ketidakadilan gender. Pendidikan setidak-tidaknya dapat membantu perempuan untuk lebih memahami kemampuan yang dimilikinya, memperbaiki kemampuannya dalam mengambil keputusan dan berpartisipasi dalam komunitas. Gagasan tersebut tidak akan terwujud jika tidak ada perubahan relasi gender dan kepercayaan pada budaya. Pendidikan mampu meningkatkan daya tawar perempuan dalam rumah tangga mengingat kemampuannya dalam pengetahuan, skill dan sumber daya guna menentukan pilihan dalam kehidupan untuk mencapai kesejahteraan (Lunberg \& Pollak 1993; Duflo, 2012).

Proses pembangunan yang dilakukan oleh suatu negara tidak terlepas dari kebijakan pemerintah atau yang dikenal dengan kebijakan nasional atau publik. Di tengah penyebaran Covid-19 ini kebijakan nasional yang dikeluarkan pemerintah pusat belum diterima dan dipahami secara benar oleh beberapa kalangan masyarakat. Perempuan sebagai anggota masyarakat belum sepenuhnya mendapatkan informasi yang benar dari kebijakan pemerintah terutama anggota PKK dari Desa Wirogunan Kecamatan Kartasura, Kabupaten Sukoharjo. Pada awal penyebaran virus Corona atau yang dikenal dengan Covid-19, beberapa anggota kelompok PKK terutama yang sudah berusia lebih dari 50 tahun belum memahami mengapa bisa menyebar dari satu negara ke negara lain dan dengan apa penyebaran tersebut bisa terjadi. Kelompok ini juga belum menerima sepenuhnya kebijakan pemerintah terkait larangan untuk meninggalkan rumah kalau tidak terpaksa, penggunaan masker jika keluar rumah dan jaga jarak. Kebimbangan yang dialami oleh para perempuan tersebut disebabkan karena belum pahamnya tentang bahaya yang ditimbulkan dari penyebaran virus yang mematikan tersebut. Beberapa anggota PKK tersebut belum paham bahwa kebijakan pemerintah di satu sisi bersifat memaksa dan mengekang namu pada sisi lainnya dimaksudkan untuk menjaga agar masyarakat terbebas dari penyakit yang ditimbulkan dari virus tersebut.

Di sinilah pentingnya memberikan literasi kepada para perempuan khususnya anggota PKK tentang kebijakan nasional yang dikeluarkan oleh pemerintah pusat. Transfer teknologi dan pengetahuan diberikan kepada anggota PKK mengingat sebagian besar adalah perempuan yang bekerja dalam rumah tangga meskipun latar belakang pendidikannya cukup beragam mulai dari SMP hingga akademi. Dengan kebiasaan dan ruang lingkup kerja yang hanya mengurus urusan domestik menjadikan sebagian anggota PKK tersebut belum dapat menerima sesuatu yang baru yang menjadikannya kurang nyaman dalam melakukan aktivitas. Kebiasaan yang dilakukan oleh anggota PKK Desa Wirogunan yang berusia diatas 50 tahun sebagai sasaran dari kegiatan ini kesehariaannya pada pagi hari adalah berbelanja untuk menyiapkan makanan bagi seluruh anggota keluarganya, membersihkan rumah dan merawat cucu karena orang tuanya bekerja. Jumlah perempuan pada kategori usia tersebut 25 orang. Keikutsertaannya dalam mengikuti kegiatan PKK juga tidak rutin yakni sejumlah 13 orang karena cucunya tidak ada yang merawat, sebanyak 7 orang hadir dengan alasan ada acara arisan. Untuk ketujuh orang tersebut mengikuti kegiatan PKK karena berharap mendapatkan uang dari arisan. Sisanya adalah anggota PKK sekaligus pengurus yang harus hadir dan mengikuti kegiatan dari awal sampai selesai. Kelompok inilah yang terkadang mencarikan nara sumber dari luar desaguna mendapatkan wawasan baru atau sharing pengalaman dari tokoh masyarakat dan akademisi atau bahkan marketing dari suatu produk. 


\section{METODE}

Metode yang digunakan dalam kegiatan ini diawali dengan memberikan sosialisasi kepada masyarakat khususnya perempuan-perempuan yang tergabung sebagai anggota PKK tingkat desa. Sebagai tahap awal kegiatan maka kegiatan sosialisasi menjadi langkah selanjutnya setelah persiapan. Tahap awal melaksanakan kegiatan ini, persiapan dilakukan dengan menyiapkan tempat pelakasanaan seperti ruangan dan perlengkapan pendukung. Tahap ini dilakukan setelah berhasil melakukan komunikasi dengan kepala desa terkait gambaran kegiatan yang akan dilakukan. Langkah selanjutnya adalah pemasyarakatan terhadap warga sekitar yang dalam hal ini direalisasikan dalam bentuk sosialisasi.

Menurut Kamus Besar Bahasa Indonesia, sosialisasi merupakan suatu kegiatan untuk menyampaikan informasi kepada masyarakat. Sebagai dampaknya, masyarakat sebagai penerima informasi menjadi mengetahui, mengerti dan merasakan adanya perubahan atau penambahan pengetahuan. Sosialisasi tersebut dilaksanakan dengan mengundang para ibu yang menjadi anggota PKK dari Desa Wirogunan Kecamatan Kartasura, Kabupaten Sukoharjo. Adapun tujuan dari kegiatan ini untuk memberikan gambaran kepada masyarakat setempat tentang peran perempuan dalam mengisi pembangunan berkelanjutan terutama ketaatannya dalam melaksanakan kebijakan nasional sebagai peraturan pemerintah dalam menghadapi Covid-19. Keterlibatan perempuan anggota PKK dalam kegiatan ini menjadi ukuran untuk melihat lebih jauh peran serta masyarakat dalam mendukung kebijakan pemerintah.

Langkah berikutnya adalah realisasi program. Kegiatan ini dimaksudkan agar sesuai dengan rencana yang telah disusun sebelumnya. Realisasi program yang dilakukan dalam bentuk pendidikan dan pendampingan literasi secara non formal. Kegiatan ini dilakukan dengan mendatangkan akademisi dari lembaga pendidikan tinggi yakni Universitas Slamet Riyadi Surakarta. Pada waktu itu pendidikan literasi non formal secara teknis dilakukan oleh mahasiswa sedangkan pendampingan secara online khususnya melalui WhatsApp Group dilakukan oleh dosen dari perguruan tinggi yang sama. Mahasiswa dalam waktu dua minggu memberikan wawasan tentang Virus Corona atau Covid-19 serta kebijakan nasional di tengah Covid-19. Setelah waktu dua minggu tersebut para anggota PKK tetap dapat melakukan komunikasi dengan para akademisi khususnya dengan tenaga pengajar (dosen) secara online.

Langkah terakhir adalah menyusun evaluasi terhadap kegiatan yang telah dilakukan. Evaluasi menurut Wirawan (2012) merupakan kegiatan menghimpun, mengkaji dan menyampaikan informasi yang berguna mengenai sasaran dan evaluasi dari suatu kegiatan yang telah dilakukan. Hasil yang diperoleh dari kegiatan evaluasi dapat dipertimbangkan, diperhitungkan dan dibandingkan guna mendapatkan poin penting dari kegiatan yang telah diselesaikan. Dalam kegiatan ini, tahap evaluasi dilakukan setelah selesai pelaksanaan pelatihan terkait kebijakan pemerintah (kebijakan nasional) dalam menghadapi pandemi Corona. Evaluasi dilakukan melalui diskusi antara mahasiswa, dosen, dan tokoh masyarakat (kepala kelurahan/lurah) dan ketua Tim Penggerak PKK dari Desa Wirogunan, Kecamatan Kartasura, Kabupaten Sukoharjo.

\section{HASIL DAN PEMBAHASAN}

Kegiatan pengabdian kepada masyarakat yang dilakukan oleh Tim dari Fakultas Ilmu Sosial dan Politik (Fisip) Universitas Slamet Riyadi Surakarta (Unisri) dipusatkan di Desa Wirogunan, Kecamatan Kartasura, Kabupaten Sukoharjo. Desa Wirogunan berasal dari kata Wiro dan Guna. Kata Wiro atau Wira berarti ksatria atau perwira sedangkan Guna berarti berguna atau bermanfaat sehingga kalau digabung menjadi ksatria yang bermanfaat. Artinya bahwa penduduk dari Desa Wirogunan diharapkan menjadi masyarakat yang memiliki jiwa ksatria agar bisa bermanfaat bagi sesama. 
Dilihat dari asal usulnya, Desa Wirogunan merupakan petilasan dari tempat tinggal Pangeran Wiroguna, seorang kepercayaan dari Sunan Pakubuwana 11. Desa Wirogunan terdiri dari 11 Rukun Tetangga (RT) dan enam Rukun Warga (RW) serta 2 kebayanan. Kondisi sejarah seperti itulah yang menjadikan desa ini memiliki tempat keramat yang sering dikunjungi bayak orang pada hari tertentu yakni makam dari Pangeran Wiroguna beserta sendang Wirogunan. Saat ini kehidupan masyarakatnya cukup beragam yang didominasi dengan usaha mandiri, buruh, dan pegawai. Sementara perempuannya yang telah menikah lebih banyak yang tinggal di rumah sebagai ibu rumah tangga atau membuka usaha rumahan dan online.

Peningkatan literasi bagi perempuan yang tergabung dalam PKK mengenai kebijakan pemerintah sangat penting terlebih saat menghadapi pandemi Virus Corona seperti sekarang ini. Kegiatan memberikan literasi tersebut dilakukan secara manual melalui pertemuan langsung yang dilaksanakan pada awal dan pertengahan bulan Februari yakni tanggal delapan dan 15. Kegiatan ini awalnya diinspirasi oleh ketua Tim Penggerak PKK yang melakukan diskusi dengan akademisi dari Unisri.

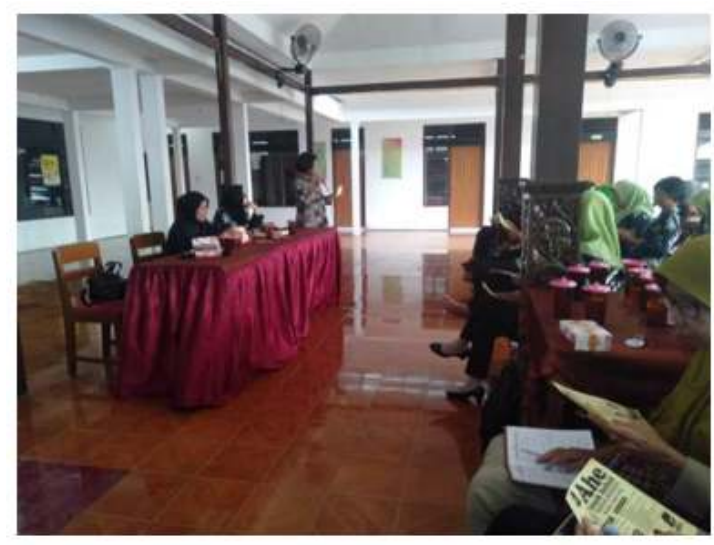

Gambar 1. Kegiatan litrasi di Wirogunan

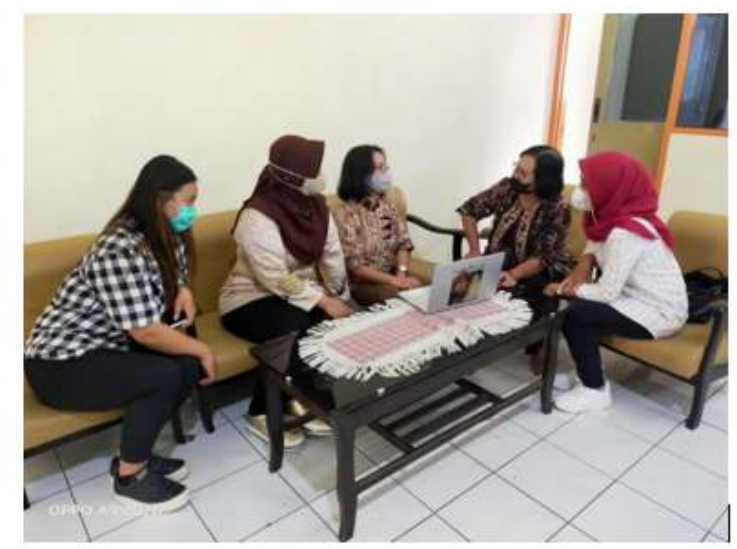

Gambar 2. Evaluasi kegiatan

Diskusi tersebut membahas mengenai apa dan bagaimana ada virus yang mematikan yang bermula dari Wuhan China bisa menyebar ke berbagai negara, apa ada kaitan antara negara yang satu dengan negara lain dan bagaimana kalau sampai pemerintah pusat mengeluarkan kebijakan yang menjadikan anggota masyarakat tidak nyaman. Hasil dari diskusi adalah rencana untuk diselenggarakannya pelatihan yakni literasi bidang politik untuk meningkatkan pemahaman masyarakat terhadap kebijakan pemerintah. Tujuan dari kegiatan tersebut selain masyarakat menjadi paham, mengerti tentang kebijakan pemerintah sekaligus juga terjadinya perubahan sikap baik dalam menjaga kebersihan, kesehatan dan ketaatan pada peraturan pemerintah.

Hasil diskusi tersebut sekaligus merupakan bentuk perijinan yang dikeluarkan oleh Ketua Tim Penggerak PKK desa Wirogunan kepada Tim Pengabdian Kepada Masyarakat dari Unisri. Dari sinilah kegiatan pengabdian kepada masyarakat dimulai. Sesuai dengan metode yang telah diuraikan pada bagian sebelumnya bahwa pada tahap awal melaksanakan kegiatan ini, persiapan dilakukan dengan menyiapkan tempat pelakasanaan seperti ruangan dan perlengkapan pendukung yakni speaker, LCD, taplak meja, meja kursi. Kegiatan ini dilakukan dan dikoordinir oleh mahasiswa sebanyak dua orang beserta perwakilan dari pengurus PKK setempat. Mahasiswa juga berkoordinir terkait ketersediaan snack dan absen bagi peserta.

Langkah berikutnya adalah pemasyarakatan atau yang dikenal dengan sosialisasi yang dilaksanakan pada hari Sabtu tanggal 8 Pebruari 2020 pukul 16.00-17.30. Pada tahap ini materi yang diberikan diawali dengan perkenalan dengan Tim Pengabdian Unisri Surakarta. Tim sekaligus menjelaskan bahwa kegiatan tersebut menjadi bagian dari Tri Dharma Perguruan Tinggi khususnya Pengabdian kepada Masyarakat yang dilakukan oleh akademisi (dosen dibantu 
mahasiswa) sehingga tidak dipungut biaya dan meyakinkan kepada peserta bahwa informasi yang diberikan tidak bernuansa hoax (mengandung berita bohong). Pada tahap ini Tim Pengabdian sekaligus menginformasikan bahwa jika masih ada peserta merasa ragu terhadap informasi yang disampaikan bisa mengkonfirmasinya dengan media massa.

Langkah selanjutnya adalah penyampaian materi sekaligus pelatihan yang dilaksanakan pada tanggal 15 Pebruari 2020. Kegiatan ini dilaksanakan pada hari Sabtu pukul 16.00-17.30. Hari Sabtu menjadi pilihan yang tepat mengingat pada hari tersebut para peserta sudah berkurang aktivitasnya. Pada kegiatan ini tokoh masyarakat yang hadir adalah Ketua Tim Penggerak PKK tingkat desa dan tiga orang perwakilan dari kecamatan, Kepala Desa, dua dosen pemberi materi beserta dua mahasiswa sehingga keseluruhan yang hadir mencapai 30 orang. Secara umum acara berjalan lancar serta sesuai dengan waktu yang telah direncanakan. Acara pelatihan ini juga diwarnai dengan keaktifan peserta sehingga tanya jawab bisa berjalan dan kegiatan menjadi lebih hidup.

Kegiatan ini diawali dengan pembukaan yang ditandai dengan penyampaian kata sambutan dari Kepala Desa, Ketua Penggerak PKK dan perwakilan dari kecamatan. Peserta sebelumnya telah melakukan regristerasi dengan memberikan tanda tangan sebelum mengikuti kegiatan. Pemateri pertama-tama menyampaikan tentang apa dan bagaimana proses penyebaran Virus Corona atau Covid-19. Selanjutnya pemateri menguraikan bahwa seseorang yang terkena virus tersebut dan melakukan perjalanan dapat menularkannya kepada orang lain. Cepatnya penularan penyakit tersebut salah satu faktor pendukungnya adalah aktivitas yang dilakukan masyarakat bukan hanya pada level lokal tapi juga nasional bahkan internasional. Ketika seseorang pernah melakukan perjalanan jauh baik luar kota, luar pulau atau luar negeri dan kembali ke wilayah asalnya bisa mempermudah penularan virus tersebut.

Untuk mengantisipasi percepatan terjadinya penularan akibat virus yang mematikan tersebut, pemerintah pusat telah mengeluarkan peraturan. Peraturan tersebut antara lain untuk menghindari bepergian kalau tidak terpaksa dan jika keluar rumah wajib mengenakan masker. Pemerintah juga mengharuskan untuk sering-sering mencuci tangan guna menjaga kebersihan bahkan kalau sehabis bepergian dianjurkan untuk segera mandi. Komunikasi yang dilakukan secara langsung antara satu orang dengan yang lain hendaknya menjaga jarak sekitar satu meter. Kesemua aturan pemerintah tersebut diuraikan secara jelas dan mendetail oleh pemateri guna meningkatkan pemahaman masyarakat terhadap bahaya yang ditimbulkan dari virus tersebut.

Materi lain yang disampaikan oleh Tim Pengabdian adalah mengenai pemilahan informasi mengenai virus Corona dari media sosial agar bisa diketahui mana yang benar dan yang mengandung kebohongan (hoax) dalam bentuk pelatihan. Tim pengabdian dalam memberikan materi tidak hanya bersifat satu arah. Komunikasi yang berlangsung terlihat cukup aktif dan dua arah sehingga kesempatan bagi peserta untuk mengajukan pertanyaan diberi waktu longgar. Pertanyaan yang disampaikan peserta antara lain bagaimana melakukan kegiatan tanpa harus sering meninggalkan rumah, sebagai perempuan yang hanya berkecimpung dalam urusan rumah tangga bagaimana memberitahu suaminya tentang aturan dari pemerintah yang terlihat mengekang, dan bagaimana perempuan dapat mengakses informasi tentang Covid-19 mengingat selama ini masih sangat tergantung pada laki-laki. Dengan kata lain, masyarakat masih menganggap bahwa sumber informasi berasal dari laki-laki sehingga kurangnya kesempatan bagi perempuan untuk lebih mandiri.

Sebagai evaluasi dari kegiatan pengabdian kepada masyarakat ini diantaranya adalah: (1) kurangnya pengetahuan yang dipengaruhi oleh rendahnya tingkat pendidikan dan skill yang kebanyakan dialami oleh perempuan pedesaan menjadikannya kurang mandiri dalam menentukan pilihan; (2) masih banyaknya perempuan yang tergantung pada laki-laki yakni suaminya dalam menentukan keputusan; (3) perempuan seringkali menjadi obyek yang mudah dipengaruhi oleh kelompok lain seperti teman atau komunitas. Hal ini bisa terlihat ketika perempuan yang sudah terbiasa menggunakan gawai begitu mendapat informasi akan segera dishare kepada orang lain. 
Untuk memperkuat pemahaman para ibu anggota PKK pada kegiatan tersebut, peserta diberi kesempatan untuk bisa berkomunikasi dengan pemateri terkait informasi mengenai virus melalui grup WhatsApp. Tim pengabdian juga mengajak peserta agar tetap tinggal dan melakukan aktivitas dari rumah guna jika memungkinkan, selalu memakai masker kalau ke luar rumah, mencuci tangan atau memakai hand sanitizer setiap hendak melakukan aktivitas yang menggunakan tangan, dan menghindari keramaian. Semua informasi tersebut diharapkan dapat membantu peserta pentingnya upaya guna memperlambat penyebaran virus.

\section{KESIMPULAN}

Kegiatan yang telah dilaksanakan melalui pemberian literasi politik kepada anggota PKK Desa Wirogunan Kecamatan Kartasura Kabupaten Sukoharjo tersebut berjalan lancar dan berdampak positif. Selama proses kegiatan anggota PKK tidak hanya memberikan perhatian kepada para pembicara namun juga mengajukan pertanyaan dan terlibat dalam kegiatan diskusi maupun pelatihan meskipun pada pertemuan awal terlihat adanya keraguan walaupun dalam jumlahnya tidak banyak. Setelah selesai kegiatan, sebagian anggota PKK masih aktif melakukan diskusi dan bertanya jawab dengan akademisi khususnya dosen yang memberikan materi secara online yakni WhatsApp. Berdasarkan hasil diskusi dan tanya jawab secara online tersebut didapatkan informasi adanya pemahaman dan perubahan sikap dari sebagian anggota PKK yang telah berusia lebih dari 50 tahun dalam menyikapi kebijakan pemerintah. Kelompok ini tidak lagi merasa dikekang dan dihalang-halangi kegiatannya sehari-hari namun justru merasa bersyukur dengan aturan pemerintah tersebut dapat menghindarkannya dan keluarganya dari penyakit.

\section{DAFTAR PUSTAKA}

Agarwal, B. (1994). A Field of One's Own: Gender and Land Rights in South Asia. Cambridge University Press.

Alvarez, M. L. (2013, October). From Unheard Screams to Powerful Voices: A Case Study of Women's Political Empowerment in the Philippines. In 12th National Convention on Statistics (pp. 1-73).

Bhalotra, S., Venkataramani, A., \& Walther, S. (2018). Fertility and labor market responses to reductions in mortality. Available at SSRN 3213304.

Duflflo, E. (2012). Women's Empowerment and Economic Development. Journal of Economic Literature, 50(4), (1051-1079).

Esquivel, V. (2016). Power and the Sustainable Development Goals: a feminist analysis. Gender \& Development, 24(1), 9-23.

García-Moreno, C., \& Amin, A. (2016). The sustainable development goals, violence and women's and children's health. Bulletin of the World Health Organization, 94(5), 396.

Jewkes, R., Morrell, R., Hearn, J., Lundqvist, E., Blackbeard, D., Lindegger, G., ... \& Gottzén, L. (2015). Hegemonic masculinity: combining theory and practice in gender interventions. Culture, health \& sexuality, 17(sup2), 112-127.

Lundberg, S., \& Pollak, R. A. (1993). Separate spheres bargaining and the marriage market. Journal of Political Economy, 101(6), (988-1010).

Murphy, K. (2012). The social pillar of sustainable development: a literature review and framework for policy analysis. Sustain. Sci. Pract. Policy 8 (1), (15-29). 
Probosiwi, R. (2015). Perempuan dan Perannya dalam Pembangunan Kesejahteraan Sosial, Natapraja, Jurnal Kajian Ilmu Administrasi Negara, Vol. 3 No. 1, (41-56).

Samarakoon, S., \& Parinduri, R. A. (2015). Does education empower women? Evidence from Indonesia. World Development, 66, 428-442.

Sen, A. (1990). More than 100 Million Women are Missing. The New York Review of Books, 37 (20).

Sullivan, N. (1994). Masters and Managers: A Study of Gender Relations in Urban Java. St. Leonards, Allen \& Unwin.

Wirawan. (2012). Evaluasi: Teori, Model, Standar, Aplikasi, dan Profesi. PT. Raja Grafindo Persada. 